\section{TÀI LIÊU THAM KHẢO}

1. Globocan. Colorectal cancer incidence and mortality worldwide in 2018. International agency for research on cancer. 2018

2. Elwanis MA, Maximous DW, Elsayed MI, Mikhail NN. Surgical treatment for locally advanced lower third rectal cancer after neoadjuvent chemoradiation with capecitabine: prospective phase II trial. World journal of surgical oncology. Jun 92009

3. Phạm Cẩm Phương. Đánh giá hiệu quả của xạ trị kết hợp capecitabine trước mổ trong ung thư trực tràng thấp tiến triển tai chô. Luân án Tiến sỹ. Trường Đại học Y Hà Nội; 2013

4. Pham Khánh Toàn. Nhận xét môt số đăc điểm lâm sàng, cân lâm sàng và kết quả xạ trị gia tốc tăng phân liều trước mổ ung thư trực tràng giai đoan T3-T4. Luân văn Thac sỹ y hoc. Trường Đai học Y Hà Nội; 2013

5. HammadTeama A, AbdelsamieAlarabawy $R$,
AbdelhadyMohamed $\mathrm{H}$, HanyEissa $\mathrm{H}$. The Egyptian Journal of Radiology and Nuclear Medicine. ScienceDirect. 2015;46(4):833- 846.

6. Sun YS, Li XT, Zhang XY, Tang L, Cui Y, Zhang $\mathbf{X P}$. [Preoperative staging of rectal carcinoma with high-resolution MRI: correlation with histopathologic findings]. Zhonghua wai ke za zhi [Chinese journal of surgery]. Mar 2012; 50(3):207-10.

7. Võ Văn Xuân, Nguyến Đại Bình, Ngô Vĩ Dung. Nghiên cứu áp dung kỹ thuất xa tri gia tốc tăng phấn liều tiên phẩu kểt hợp với phẩu thuật ung thư trực tràng. Tap chí Ung thư hoc Viêt Nam. 2012; 2:57-66.

8. Kim JC, Kim TW, Kim JḦ, et al. Preoperative concurrent radiotherapy with capecitabine before total mesorectal excision in locally advanced rectal cancer. International journal of radiation oncology, biology, physics. Oct 1 2005;63(2):346-53.

9. Chamlou R, Parc Y, Simon T, et al. Long-term results of intersphincteric resection for low rectal cancer. Annals of surgery. Dec 2007;246(6):91621; discussion 921-2.

\title{
ĐÁNH GIÁ KẾT QUẢ PHẪU THUÂT VÁ NHĨ TRONG ĐIỀU TRI VIÊM TAI GIŨ̃ A MAN TÍNH KHÔNG NGUY HIỂM Ở TRẺ EM DƯớI 16 TUỔI
}

\section{TÓM TẮT}

Mục tiêu: Đánh giá kết quả phẫu thuật vá nhĩ trong điều trị viêm tai giữa mạn tính không nguy hiểm ở trẻ em đồ tuổi dưới 16. Phương pháp nghiên cứu: mô tả cắt ngang có can thiệp. Địa điểm nghiên cứu: Bênh viên Đai hoc Y Hà Nôi và Bênh viên Tai Mũi Họng Trung ương. Bệnh nhân: 29 bệnh nhân viêm tai giữa man tính không nguy hiểm trong đô tuổi từ 816 tuổi được phẫu thuật vá nhĩ từ 6/2020- 8/2021. Kết quả: Tỷ lệ đóng kín lỗ thủng màng nhĩ sau phẫu thuâtt trên 6 tháng chiếm $86,2 \%$, PTAac trước phẫu thuẩt là 28,06 dB sau phẫu thuât 20,86 dB, ABG trước phẫu thuật là 24,13 dB sau phấu thuật 14,66 dB. Kết luân: Tỷ lệ vá nhĩ thành công trong điều trị viêm tai giữa mạn tính không nguy hiểm ở trẻ em độ tuổi 8- 16 là tương đương với người lớn.

Tư khóa: Phẫu thuâtt vá nhĩ trẻ em, phẫu thuật tạo hình tai giữa typ 1 ở trẻ em

\section{SUMMARY \\ OUTCOME ASESSMENT OF TYMPANOPLASTY SURGERY MEASURE FOR CHRONIC OTITIS MEDIA TREATMENT WITHOUT CHOLESTEATOMA}

*Bệnh viện trẻ em Hải phòng

**Trướng Đai hoc Y Hà Nôi

Chịu trách nhiệm chính: Bùi Duy Vũ

Email: anhvu1981hy@gmail.com

Ngày nhận bài: 29.7.2021

Ngày phản biên khoa hoc: 29.9.2021

Ngày duyệt bài: 5.10 .2021
Bùi Duy Vũ *, Cao Minh Thành**

IN THE PEDIATRIC UNDER 16 YEARS

Objective: the purpose of this study was assess the value of tympanoplasty surgery measure for chronic otitia media treatment without cholesteatoma in the pediatric under 16 years. Methods: crosssectional descriptive study. Place of study: In National ENT Hospital and Ha Noi Hospital university of medicine.Patients: twenty nine patients were operated closure of tympntic membrane perforation aged between 8 and 16 years from June 2020 to August 2021. Results: the prevalent of closure of tympanic membrane perforation occupied $86,2 \%$ after 6 months surgery. Preoperative PTAac was $28.06 \mathrm{~dB}$ compared to 20,86 dB Postopertive. Preoperative ABG was $24,13 \mathrm{~dB}$ compared to $14,66 \mathrm{~dB}$ Postopertive. Conclusion: tympanoplasty success rates for treatment of no danger otitis media in pediatric population aged between 8 and 16 years were similar to adults.

Keywords:Tympanoplasty in pediatric patients,Typ 1 tympanoplasty in pediatric pateints.

\section{I. ĐĂTT VẤN ĐỀ}

Viêm tai giữa mạn tính (VTGMT) là bệnh thường gặp ở Việt Nam và trên thế giới, nhất là ở trẻ em. Phẫu thuật vá nhĩ (tạo hình tai giữa typ I) là phương pháp cơ bản để điêuu trị VTGMT không nguy hiểm. Phẫu thuật tạo hình tai giữa (THTG) được Wüllstein và Zöller phổ biến vào giữa những năm 19501,2,3. Các lý do được đưa ra làm kết quả phẫu thuật vá nhĩ của trẻ em kém 
hơn người lớn như: tần suất nhiễm trùng đường hô hấp trên và viêm tai giữa cao hơn, chức năng vòi eustachian kém hơn, VA quá phát và hệ thống miễn dịch chưa trưởng thành ${ }^{2}$. Những lập luận này dẫn đến việc trì hoãn việc THTG ở trẻ em, đặc biệt với trẻ em < 14 tuổi. Tuy vậy, các nghiên cứu trên thế giới gần đây cho thây, phẫu thuật vá nhĩ ở trẻ em có tỷ lệ thành công là gần tương tự như người lớn ${ }^{3}$. Sự xuất hiện của nghe kém trong thời thơ ấu có ảnh hưởng không tốt đến sự phát triển của lời nói, ngôn ngữ, tư duy và các kỹ năng học tập ${ }^{2,3}$. Bên cạnh đó, việc đóng lỗ thủng màng nhĩ sẽ ngăn ngừa sự hình thành cholesteatoma và tổn thương xương con về lâu dài. Phẫu thuật THTG thành công mang lại cho trẻ một đôi tai an toàn, không chảy dịch, không cần chăm sóc cũng như tham gia các hoạt động dưới nước và các hoạt động xã hội khác mà không bị hạn chế. Vì vậy, chúng tôi nghiên cứu đề tài này với mục tiêu: "Đánh giá kết quả phẫu thuật vá nhĩ trong điều trị viêm tai giữa mạn tính không nguy hiếm ở trẻ em độ tuổi 8-16".

\section{II. ĐỐI TƯợNG VÀ PHƯƠNG PHÁP NGHIÊN CỨU \\ 2.1 Đối tượng nghiên cứu}

- Bệnh nhân trong độ tuổi 8- 16 được chẩn đoán VTGMT không nguy hiểm, được khám và điều trị tại Bệnh viện Tai mũi họng trung ương và Trung tâm Tai mũi họng và Phẫu thuật cây ốc tai Bệnh viện Trường đại học $Y$ Hà Nội.

- Thời gian: 6/2020-8/2021, N=29bệnh nhân.

\subsubsection{Tiêu chuẩn lựa chọn}

- Tuổi: 8- 16 tuổi.

- Bệnh nhân được chẩn đoán VTGMT không nguy hiểm giai đoạn ổn định: tai khô $\geq 12$ tuần, nội soi: màng nhĩ thủng, tai khô, đáy nhĩ sạch. Đo sức nghe: nghe kém dẫn truyền hoặc hỗn hợp. Phim cắt lớp vi tính (CLVT) xương thái dương: không có ổ tiêu xương và tổn thương xương con.

- Đủ điều kiện phẫu thuật

- Được phẫu thuật vá màng nhĩ.

- Đánh giá kết quả sau phẫu thuật về: màng nhĩ và sức nghe ở những thời điểm 1, 3, 6 tháng và trên 6 tháng.

\subsubsection{Tiêu chuẩn loại trừ}

- Bệnh nhân $<8$ tuổi và $\geq 16$ tuổi.

- Bệnh nhân không khám lại sau mổ 1 tháng, 3 tháng, 6 tháng và trên 6 tháng hoặc khám lại sau 6 tháng không đo sức nghe đơn âm.

- VTGMT nguy hiểm.

- Gia đình bệnh nhân hoặc người giám hộ không đồng ý tham gia nghiên cứu.

2.2. Phương pháp nghiên cứu
2.2.1. Thiết kế nghiên cứu: mô tả cắt ngang ca bệnh có can thiệp.

\subsubsection{Phương tiện nghiên cứu}

- Bênhh án nghiên cứu mẫu.

- Thiết bị nghiên cứu: Bộ nội soi tai mũi họng, máy đo thính lực đơn âm, kính hiển vi phẩu thuật, máy chụp phim CLVT xương thái dương, bộ dụng cụ phẩu thuật tai.

- Chất liệu vá màng nhĩ : cân cơ thái dương.

\subsubsection{Các thông số nghiên cứu}

- Nhóm tuổi, tuổi trung bình, thời gian bị bệnh, thời gian theo dõi sau phẫu thuật

- Lỗ thủng màng nhĩ: vị trí, kích thước

- Cận lâm sàng: + Thính lực đồ: loại nghe kém, PTAac, PTAbc, ABG

+ CLVT xương thái dương

- Kết quả: Nội soi màng nhĩ: rất tốt, tốt, trung bình, thất bại

\section{Chức năng: PTAac, ABG sau mổ}

2.2.4. Các tiêu đánh giá kết quả sau phẫu thuật. Đánh giá thành công về mặt giải phẫu (độ liền của màng nhĩ) và chức năng (PTAac, ABG):

*Màng nhî:: Rất tốt: Màng nhĩ liền kín, bóng sáng.

Tốt: Màng nhĩ liền kín, khô, dày.

Trung bình: Màng nhĩ liền ẩm, lõm.

Thất bại: Màng nhĩ thủng lại hoặc không liền kín. *Sức nghe: Rất tốt: PTAac $\leq 10 \mathrm{~dB}, \mathrm{ABG} \leq 10 \mathrm{~dB}$.

Tốt: PTAac: từ 11- $20 \mathrm{~dB}$; $A B G$ : từ 11- $20 \mathrm{~dB}$.

Trung bình: PTAac: từ 21- $30 \mathrm{~dB}, \mathrm{ABG}$ : từ 21$30 \mathrm{~dB}$.

Kém, thất bại: PTAac $>30 \mathrm{~dB}, A B G>30 \mathrm{~dB}$

2.2.5. Phương pháp xử lý số liệu: Xử lý số liệu bằng phần mềm SPSS 20.0

\section{KẾT QUẢ NGHIÊN CỨU}

\section{1 Đặc điểm chung}

- Phân loại theo nhóm tuổi: Nhóm tuổi 12$<16$ tuổi chiếm tỷ lệ cao hơn 23/29 (79,3\%), nhóm tuổi 8-11 tuổi thấp hơn 6/29 (20,7 \%).

- Tuổi trung bình: 12,66 $\pm 1,99$ tuổi, tuổi nhỏ nhất là 8 tuổi, tuổi lớn nhất là 15 tuổi.

- Theo thời gian bị bệnh: bệnh nhân có thời gian bị bệnh $>5$ năm chiếm tỷ lệ $79,3 \%$, nhóm 1-5 tuổi chiếm tỷ lệ 20,7\%, không có trường hợp nào bị bệnh <1 năm.

- Thời gian theo dõi sau phẫu thuật:

Trung bình: 11,02 $\pm 0,92$ tháng, ngắn nhất 7 tháng, dài nhất 13 tháng.

3.2 Đặc điểm lâm sàng và cận lâm sàng trước phẫu thuâat

3.2.1 Đặc điểm lỗ thủng màng nhĩ

Bảng 3.1. Đắc điểm tổn thương màng nhĩ theo vị trí lổ thủng $(\mathrm{N}=29)$ 
VIETNAM MEDICAL JOURNAL N² - OCTOBER - 2021

\begin{tabular}{|c|c|c|}
\hline Vị trí lố thưng màng nhĩ & $\mathbf{n}$ & $\mathbf{\%}$ \\
\hline Trước trên & 0 & 0,0 \\
\hline Trước dưới & 3 & 10,3 \\
\hline Sau trên & 1 & 3,4 \\
\hline Sau dưới & 1 & 3,4 \\
\hline Trung tâm & 2 & 6,9 \\
\hline Thủng rộng màng căng & 22 & 75,9 \\
\hline $\mathrm{N}$ & 29 & 100 \\
\hline
\end{tabular}

Nhận xét; Lỗ thủng rộng màng căng chiếm $75,9 \%$, các vị trí lỗ thủng góc trước dưới, sau trên, sau dưới và trung tâm có tỷ lệ lần lượt là

$10,3 \%, 3,4 \%, 3,4 \%$ và 6,9\%. Không có bệnh nhân nào bị thủng góc trước trên.

Bảng 3.2. Phân bố bệnh nhân theo kích thước lỗ thủng

\begin{tabular}{|c|c|c|}
\hline Kích thước lố thủng & $\mathbf{n}$ & $\mathbf{\%}$ \\
\hline Nhỏ $\leq 1 / 4$ màng nhĩ & 4 & 13,8 \\
\hline $1 / 4<$ Trung bình $\leq 1 / 2$ màng nhĩ & 3 & 10,3 \\
\hline Rộng >1/2 màng nhĩ & 22 & 75,9 \\
\hline N & 29 & 100 \\
\hline
\end{tabular}

Nhân xét: Lỗ thủng rộng chiếm 75,9\%, lỗ thủng nhỏ chiếm $13,8 \%$, lỗ thủng trung bình là 10,3\%

3.3.2. Đặc điểm sức nghe trước phẫu thuật.

Bảng 3.3. Trung bình ngưỡng nghe trước phẫu thuật $(N=29)$

\begin{tabular}{|c|c|c|c|c|c|}
\hline $\begin{array}{l}\text { Tân số }(\mathrm{kHz}) \\
\text { Cường độnghe }(\mathrm{dB})\end{array}$ & 0,5 & 1 & 2 & 4 & PTA \\
\hline$B C$ & $5,21 \pm 4,07$ & $3,97 \pm 4,89$ & $5,86 \pm 5,68$ & $0,52 \pm 5.57$ & $3,93=$ \\
\hline $\mathrm{AC}$ & & & & $25,69 \pm$ & \\
\hline$A B G$ & $27,38 \pm 12,37$ & $24,83 \pm 10,39$ & $17,59 \pm 7,02$ & $25,17 \pm 9,86$ & $24,13 \pm 7,13$ \\
\hline
\end{tabular}

Nhận xét: PTAbc là $3,93 \mathrm{~dB}$, nằm trong giới hạn bình thường, PTAac có giá trị $28,06 \mathrm{~dB}$, thuộc loại nghe kém mức độ nhẹ, $A B G$ có giá trị $24,13 \mathrm{~dB}$.

3.3.3. Đăc điểm phim cắt lớp vi tính xương thái dương (CLVTXTD)

- Có 26/29 bệnh nhân biểu hiện khối mờ trên phim CLVTXTD chiếm tỷ lệ 89,7\%, có 3/29 bệnh nhân $(10,3 \%)$ không có biểu hiện tổn thương trên phim CLVTXTD

- Không có bệnh nhân nào có biểu hiện tổn thương gián đoạn xương con và ổ tiêu xương

3.3 Kết quả sau phẫu thuật

Bảng 3.4. Tỷ lệ màng nhĩ liền lỗ thủng sau phẫu thuật

\begin{tabular}{|c|c|c|c|c|c|c|c|c|}
\hline \multirow{2}{*}{$\begin{array}{l}\text { Thời gian phấu thuật } \\
\text { Tình trạng màng nhĩ }\end{array}$} & \multicolumn{2}{|c|}{1 tháng } & \multicolumn{2}{|c|}{3 tháng } & \multicolumn{2}{|c|}{6 tháng } & \multicolumn{2}{|c|}{ >6 tháng } \\
\hline & $\mathbf{n}$ & $\%$ & $\mathbf{n}$ & $\%$ & $\mathbf{n}$ & $\%$ & $\mathbf{n}$ & $\%$ \\
\hline Lố thủng liền, ấm & 6 & 20,7 & 0 & 0,0 & 0 & 0,0 & 0 & 0,0 \\
\hline Lồ thủng liền, khô & 19 & 65,5 & 0 & 0,0 & 0 & 0,0 & 0 & 0,0 \\
\hline Lố thủng không liền kín & 4 & 13,8 & 2 & 6.9 & 0 & 0,0 & 0 & 0,0 \\
\hline Lỗ thủng liền, dày & 0 & 0,0 & 7 & 24,1 & 4 & 13,8 & 4 & 13,8 \\
\hline Lồ thủng liền, bóng & 0 & 0,0 & 20 & 69,0 & 22 & 75,9 & 21 & 72,4 \\
\hline Lố thủng màng nhĩ & 0 & 0,0 & 0 & 0,0 & 3 & 10,3 & 4 & 13,8 \\
\hline $\mathrm{N}$ & 29 & 100 & 29 & 100 & 29 & 100 & 29 & 100 \\
\hline
\end{tabular}

Nhận xét: Tỷ lệ màng nhĩ liền kín sau phầu thuật 1 tháng, 3 tháng, 6 tháng và trên 6 tháng tương ứng là $86,2 \%, 93,1 \%, 89,7 \%$ và $86,2 \%$. Tỳ lệ màng nhĩ liên không kín sau phẫu thuật 1 tháng, 3 tháng tương ứng là $13,8 \%, 6,9 \%$. Tỷ lệ màng nhĩ có lỗ thủng sau 6 tháng là $10,3 \%$ và trên 6 tháng $13,8 \%$. tuổi

Bảng 3.5. Tỷ lệ liền màng nhĩ theo nhóm

\begin{tabular}{|c|c|c|c|}
\hline \multirow{3}{*}{$\begin{array}{l}\text { Kết quả } \\
\text { điều trị }\end{array}$} & \multicolumn{2}{|c|}{ Nhóm tuối } & \multirow{3}{*}{$\stackrel{p}{p}$} \\
\hline & $\begin{array}{c}8-<12 \\
\text { tuổi }\end{array}$ & $\begin{array}{c}12-<16 \\
\text { tuổi }\end{array}$ & \\
\hline & n (\%) & & \\
\hline Thành công & $5(83,3)$ & $20(86,9)$ & \multirow{3}{*}{$>0,05$} \\
\hline Thất bại & $1(16,7)$ & $3(13,1)$ & \\
\hline $\mathrm{N}$ & $6(20,7)$ & $23(79,3)$ & \\
\hline
\end{tabular}

Nhận xét: Tỷ lệ liên màng nhĩ của nhóm 8$<12$ tuổi là $83,3 \%$, nhóm $12-<16$ tuổi là $86,9 \%$. Tỷ lệ màng nhĩ thủng lại của nhóm 8- < 12 tuổi và $12-<16$ tuổi lần lượt là $16,7 \%$ và $13,1 \%$. Sự khác biệt không có ý nghĩa thống kê, p> 0,05.
Bảng 3.6. Phân loại mức độ cải thiện $A B G$ và phục hồi màng nhĩ sau phẫu thuật Thông số đánh giá Màng nhĩ ABG \begin{tabular}{|c|c|c|c|c}
\hline Tiêu chí đánh giá & $\mathbf{n}$ & $\%$ & $\mathbf{n}$ & $\%$ \\
\hline
\end{tabular}

\begin{tabular}{|c|c|c|c|c|}
\hline Rất tốt & 21 & 72,4 & 9 & 31,0 \\
\hline Tốt & 4 & 13,8 & 13 & 44,8 \\
\hline Trung bình & 0 & 0,0 & 7 & 24,1 \\
\hline Thất bai & 4 & 13,8 & 0 & 0,0 \\
\hline N & 29 & 100 & 29 & 100 \\
\hline
\end{tabular}

Nhận xét: Quá trình phục hồi màng nhĩ và mức cải thiện $A B G$ sau phẩu thuật ở các mức là:

- Rất tốt: màng nhĩ phục hồi giải phẫu gần như bình thường chiếm tỷ lệ $72,4 \%$ và $A B G \leq$ $10 \mathrm{~dB}$ chiếm tỷ lệ $31,0 \%$

- Tốt: màng nhĩ phục hồi giải phẫu ở mức tốt 
(màng nhĩ liền, khô, dày) chiếm tỷ lệ $13,8 \%$ và ABG từ $10-20 \mathrm{~dB}$ chiếm tỷ lệ 44,8\%

- Trung bình: không có bệnh nhân nào có màng nhĩ liền ẩm (mức trung bình) $0,0 \%$ và $A B G$ từ $21-30 \mathrm{~dB}$ chiếm tỷ lệ $24,1 \%$

- Thất bại: màng nhĩ thủng lại (thất bại) sau phẫu thuât chiếm tỷ lệ $13,8 \%$ và $A B G>30 \mathrm{~dB}$ không có bệnh nhân nào $(0,0 \%)$.

Bảng 3.7. So sánh kêt quả PTAac, ABG trước và sau phẫu thuật $(N=29)$

\begin{tabular}{|c|c|c|c|}
\hline $\begin{array}{ll}\text { Thông số } & \text { Thời gian } \\
\end{array}$ & Trước phẫu thuật & Sau phẫu thuật & $\mathbf{p}$ \\
\hline PTAac & $28,06 \pm 8.28$ & $20,86 \pm 7,02$ & $<0,05$ \\
\hline ABG & $24,13 \pm 7,13$ & $14,66 \pm 5,98$ & $<0,05$ \\
\hline
\end{tabular}

Nhân xét: PTAac trước phẫu thuật là $28,06 \mathrm{~dB}$, sau phẫu thuật là $20,86 \mathrm{~dB}, \mathrm{ABG}$ trước phẫu thuật là $24,13 \mathrm{~dB}$, sau phẫu thuật là $14,66 \mathrm{~dB}$. Sự khác biệt PTAac, ABG trước và sau phẫu thuật có ý nghĩ̃a thống kê, $\mathrm{p}<0,05$.

\section{BÀN LUẬN}

\section{1 Đặc điểm chung}

Tuổi, nhóm tuổi: Phẫu thuật vá nhĩ ở trẻ em là chủ đề được thảo luận rất nhiều trong thời gian qua. Một trong những vấn đề gây tranh cãi nhất là độ tuổi tối ưu để phẫu thuật vá nhĩ ở trẻ em. Vậy, có thể tiến hành vá nhĩ cho trẻ từ độ tuổi nào? Blustone cho rằng lứa tuổi có sự hoàn thiện về chức năng vòi nhĩ là 6,7 hoặc 8 tuổi, đây là lứa tuổi có thể tiến hành vá nhî̃ ${ }^{3}$. Kock, Kumar và công sự khuyến nghị độ tuổi tối thiểu là 8 tuổi để thực hiện phẫu thuật tạo hình tai giữa, dựa trên các thành phần sụn và cơ vòi Eustachian có cấu tao hoàn thiện ${ }^{3}$. Hơn nữa, ở trẻ em 6 đến 7 tuổi VA bắt đầu có sự thoái triển ${ }^{8}$, tỷ lệ viêm đường hô hấp trên giảm, miễn dịch trưởng thành hơn. Các tác giả này đều đề nghị nên can thiệp vá nhĩ sớm cho trẻ để phục hồi chức năng tai giữa và ngăn ngừa tình trạng suy giảm thêm tai giữa ${ }^{3}$. Do vậy, chúng tôi lựa chọn trẻ em từ 8 tuổi trở lên là lứa tuổi phù hợp để phẫu thuât vá nhĩ.

Nhóm tuổi 12-16 T chiếm tỷ lệ 79,3\% cao hơn nhóm tuổi $8-<12 \mathrm{~T}(20,7 \%)$ và tuổi trung bình là 12,66 $\pm 1,99$ tuổi, tuối nhỏ nhất là 8 tuổi, lớn nhất là 15 tuổi. Thời gian bị bệnh là trên 5 năm chiếm tỷ lệ cao nhất là $79,3 \%$, có $20,7 \%$ trẻ em có thời gian bị bệnh từ 1- 5 năm, không có bệnh nhân nào có thời gian bị bệnh dưới 1 năm. Các nghiên cứu đều chỉ ra rằng: thời gian bị bệnh càng dài thì kích thước lỗ thủng càng rộng, nguy cơ tổn thương tai giữa càng cao và mức độ nghe kém càng nhiều ${ }^{2,3}$.

Thời gian theo dõi trung bình sau phẫu thuật là 11,02 tháng, ngắn nhất là 7 tháng, dài nhất là 13 tháng, thấp hơn thời gian theo dõi trung bình của tác giả Cao Minh Thành (16 tháng) $)^{7}$. Thời gian theo dõi càng dài càng có giá trị giúp phát hiện sớm các nguy cơ thất bại để có biện pháp can thiệp và rút kinh nghiệm. Đồng thời, thời gian theo dõi kéo dài giúp đánh giá kêtt quả phẫu thuật vá nhĩ về mặt giải phẫu và chức năng một cách chính xác và đây đủ hơn. Tuy nhiên, đa số các tác giả đều cho là thời gian theo dõi trên 6 tháng là có giá trị để đánh giá được thành công về mặt giải phấu và chức năng của phẫu thuật vá nhĩ ${ }^{3}$.

\section{2 Đặ̆c điểm lâm sàng, cận lâm sàng} trước phẩu thuật

Đặc điểm vị trí, kích thước lỗ thủng màng nhĩ: Màng nhĩ có thể thủng ở bất cứ vị trí nào trong quá trình viêm, có kích thước khác nhau và chủ yếu gặp ở phần màng căng. Chúng tôi gặp phần lớn bệnh nhân có lố thủng rộng phần màng căng và kích thước lỗ thủng chiếm $>50 \%$ diện tích màng nhĩ chiếm tỷ lệ cao nhất $(75,9 \%)$, cao hơn tác giả Cao Minh Thành $(23,7 \%)^{7}$, Phùng Thị Vân Anh $(38 \%)^{9}$. Lỗ thủng góc trước dưới chiếm 10,3\%. Vị trí, kích thước và hình thái lỗ thủng liên quan đến mức độ nghe kém và khả năng thành công của phẫu thuật ${ }^{2}$. Theo Pedro Salvador ${ }^{3}$, Î̃̂ thủng góc trước có kêt quả phẫu thuật kém hơn góc sau và góc dưới ( $75 \%$ so với $87,5 \%$ và $94,1 \%$ ). Lỗ thủng trung tâm chiếm $6,9 \%$, thấp hơn tác giả Cao Minh Thành $(32 \%)^{7}$. Kích thước lỗ thủng nhỏ, lỗ thủng trung bình có tỷ lệ tương ứng là $13,8 \%$ và $10,3 \%$, thấp hơn của tác giả Cao Minh Thành $(18,6 \% \text { và } 42,3 \%)^{7}$.

Ngưỡng nghe trước phẫu thuật: Trung bình ngưỡng nghe đường xương (PTAbc) nằm trong giới hạn bình thường $(3,93 \pm 3,45)$. Trung bình ngưỡng nghe đường khí (PTAac) là 28,06 $\mathrm{dB}$, nằm trong giới hạn nghe kém dẫn truyền mức độ nhẹ, thấp hơn nghiên cứu của Phùng Thị Vân $A_{n h}^{9}(35,8 \mathrm{~dB})$. Thời gian VTGMT càng dài thì mức độ suy giảm sức nghe càng nhanh và nhiều, theo Sakagami mỗi năm tai bị bệnh giảm $0.82 \mathrm{~dB}$. Đối tượng nghiên cứu của chúng tôi là trẻ em nên thời gian bị bệnh chưa quá kéo dài, lỗ thủng màng nhĩ chưa toàn bộ nên mức độ giảm sức nghe chỉ ở mức độ nhẹ. ABG có giá trị trung bình là là 24,13 dB, tương đương với 
nghiên cứu của Phùng Thị Vân Anh $(28,2 \mathrm{~dB})^{9}$. $A B G$ càng lớn thì khoảng cách giữa đường khí và đường xương càng lớn và ngược lại.

\subsection{Kết quả phẫu thuất}

Tình trạng màng nhî̃ sau phẫu thuật. Thành công về mặt giải phấu là thước đo kết quả chính và được xác định là màng nhĩ liền kín, không co rút, rung động bình thường, ít nhất 6 tháng sau phẫu thuật. Nghiên cứu gần đây của một số tác giả trên thế giới báo cáo tỷ lệ màng nhî̉ liền sau phẫu thuật dao động từ 75- 92\%3. Trong nghiên cứu của chúng tôi tỷ lệ màng nhĩ liền kín sau phẫu 1 tháng là $86,2 \%$, sau phẫu thuật 3 tháng là $93,1 \%, 6$ tháng là $89,7 \%$, trên 6 tháng là $86,2 \%$. Kết quả này cũng tương tự nghiên cứu của Pedro Salvador ${ }^{3}$ là $83 \%$, thấp hơn nghiên cứu của tác giả Cao Minh Thành $(95,9 \%)^{7}$. Tại thời điểm sau phẫu thuật 1 tháng, tỷ lệ liền màng nhĩ là $86,2 \%$ (có 20,7\% liền ẩm, liên khô là 65,5\%), thấp hơn tác giả Cao Minh Thành $(95,9 \%)^{7}$, Phùng Thị Vân Anh $(92,9 \%)^{9}$. Thời điểm sau 3 tháng, tỷ lệ liền màng nhĩ chiếm 93,1\%(69\% màng nhĩ liền bóng, 24,1\% màng nhĩ liền đục), tương tự nghiên cứu của Phùng Thị Vân Anh là $95 \%{ }^{9}(72,5 \%$ màng nhĩ liền bóng, $22,5 \%$ màng nhĩ liền dày đục). Thời điểm sau 6 tháng: tỷ lệ thành công là $86,2 \%$ (liền kín, sáng bóng chiếm $72,4 \%$, liền dày là $13,8 \%$ ), thấp hơn nghiên cứu của Phùng Thị Vân Anh là $93,1 \%$ (82,8\% màng nhĩ liền bóng sáng). Tỷ lệ thất bại trong nghiên cứu của chúng tôi là $13,8 \%$, tương tự nghiên cứu của Denis Baklaci là $13,7 \%$, cao hơn tác giả Cao Minh Thành $(9,4 \%)^{7}$.

Tỷ lệ thành công theo nhóm tuổi: tỷ lệ liền màng nhĩ ở nhóm tuổi 8- <12 là 83,3\%, nhóm $12-<16$ là $86,9 \%$, sự khác biệt không có ý nghĩa thống kê, $p>0,05$. Trong nghiên cứu của Pedro Salvador ${ }^{3}$ thì tỷ lệ liền màng nhĩ của nhóm $8-12$ tuổi và từ $12-18$ tuổi lần lượt là $83,1 \%$ và $92,8 \%, p>0,05$. Có sự khác biệt là do trong nghiên cứu của Pedro Salvador nhóm trẻ lớn nằm trong độ tuổi từ 12- 18 tuổi, nghiên cứu của chúng tôi ở nhóm tuổi trẻ lớn chỉ trong độ tuổi 12- <16 tuổi. Tuy nhiên, đa số các tác giả đều nhân thây tỷ lệ thành công của nhóm trẻ có độ tuổi bé thấp hởn nhóm độ tuổi lớn nhưng không có sự khác biệt ${ }^{2,3}$

Đánh giá sức nghe sau phẫu thuật: Phẫu thuật vá nhĩ đơn thuần nhằm mục đích cải thiên tình trạng nghe kém để tối ưu hóa sự phát triển ngôn ngữ và lời nói ${ }^{3}$. Trong nghiền cứu của chúng tôi sức nghe sau phẫu thuật có sự cải thiên đáng kể, PTAac là 20,86 dB so với trước phẩu thuật là $28,06 \mathrm{~dB}$, cải thiện được $7,20 \mathrm{~dB}$, xếp loại nghe kém nhẹ. Kết quả này tương tự kết quả trong nghiên cứu của Pedro Salvador ${ }^{3}$, mức cải thiện thính giác trung bình PTAac là 7,95 dB. Chỉ số $A B G$ trước phẫu thuật là $24,13 \mathrm{~dB}$, sau phẫu thuật là $14,66 \mathrm{~dB}$, mức thu hồi là 9,47 dB. Mức thu hồi $A B G$ sau phẫu thuật của chúng tôi tương tự kết quả của Denis Baklaci ${ }^{2}(10,77$ dB), Pedro Salvador ${ }^{3}(7,88 \mathrm{~dB})$. Kết quả này cũng tương tự nghiên cứu của Phùng Thị Vân $A n h^{9}$, PTAac và $A B G$ sau phẫu thuật $24,4 \mathrm{~dB}$ và 19,1 $\mathrm{dB}$. Mức thu hồi $\mathrm{ABG}$ sau phẫu thuật càng cao thì khả năng cải thiên sức nghe càng tốt, vì khi $A B G$ tăng cao thì khoảng cách đường khí - xương sẽ hẹp lại, mà khoảng cách đường khí - xương càng hẹp thì phục hồi sức nghe càng tốt ${ }^{7}$. Trong nghiên cứu của chúng tôi mức độ cải thiện $A B G$ $\leq 20 \mathrm{~dB}$ (mức rất tốt: $A B G \leq 10 \mathrm{~dB}$ và tốt: $A B G$ từ $11-20 \mathrm{~dB}$ ) chiếm $75,8 \%$, trong đó $A B G \leq 10$ dB là $31,0 \%, A B G$ từ $11-20$ là $44,8 \%$ cải thiên rõ rệt so với trước mổ $(0,0 \%$ và $31,0 \%)$. Mức độ cải thiện $A B G \leq 20 \mathrm{~dB}$ trong nghiên cứu của chúng tôi tương tự nghiên cứu của Denis Baklaci là 74,5\%, ABG ở mức trung bình (21- 30 $\mathrm{dB}$ ) chỉ chiếm $24,1 \%$ và không có bệnh nhân nào có $A B G \geq 31 \mathrm{~dB}$. Mức độ cải thiện PTAac sau mổ là rất rõ rệt, mức rất tốt (PTA $\leq 10 \mathrm{~dB})$, tốt (PTA từ 11- $20 \mathrm{~dB}$ ), trung bình (PTA từ 21- 30 $\mathrm{dB})$ có tỷ lệ lần lượt là $3,4 \%, 58,6 \%$ và $27,6 \%$ so với trước phẫu thuật $(0,0 \%, 17,2 \%$ và $51,7 \%)$, sự khác biệt có ý nghĩa thống kê ( $p<$ $0,05)$. Bệnh nhân có PTAac $\geq 31 \mathrm{~dB}$ chiếm $10,3 \%$, trong khi trước phẫu thuật là 31,0\%.

\section{KẾT LUÂN}

Tỷ lệ đóng kín lỗ thủng sau phẫu thuật vá nhĩ ở trẻ 8- 16 tuổi là 25/29 (86,2\%).Tỷ lê thủng màng nhĩ sau phẫu thuật là 4/29 (13,8\%). Không có sự khác nhau giữa 2 nhóm tuổi. Vá màng nhĩ thành công làm chấm dứt quá trình viêm và tăng sức nghe cho bệnh nhân.

Tỷ lệ thành công của phẫu thuật vá nhĩ ở trẻ em là gần tương đương với người lớn. Như vậy chúng ta hoàn toàn có thể chỉ định phẫu thuật vá nhĩ cho trẻ từ 8 tuổi trở lên. Phẫu thuâat vá nhĩ sớm thành công giúp: ngăn chuyển loại viêm tai, tham gia các hoạt động dưới nước, hoạt động xã hội mà không bị hạn chế. Tạo điều kiện cho trẻ tự tin hơn trong cuộc sống.

\section{TÀI LIÊU THAM KHẢO}

1. Wullstein H. Theory and practice of tympanoplasty. Laryngoscope. 1956, 66(8): 1076- 93.

2. Baklaci et al (2018), BMC Pediatrics, " Type 1 tympanoplasty in pediatric patients: a review of 102 cases". https://doi.org/10.1186/s12887-018-1326-1.

3. Pedro Salvador et al (2020), Pediatric type 1 
tympanoplasty: prognostic factors, Artículo Original, 2340- 3438.

4. Gans H. Tympanoplasty in children. Arch Otolaryngol. 1963;77:350.

5. Pyman C. Signposts to successful tympanoplasty, With special reference to children. J Otolaryngol Soc Aust. 1964;1:233-47.

6. Lau $\mathbf{T}$, Tos $\mathbf{M}$. Tympanoplasty in children. An analysis of late results. Am J Otol. 1986;7(1):55-9.
7. Cao Minh Thành (2012). Phẫu thuât nôi soi vá nhĩ: kết quả và kinh nghiệm thực tiến, Tạp chí Y học Viêt nam; tâp 393; tháng 5 số 1; trang 76-79.

8. Anita Jeyakumar, Sean Miller, Ron B. Mitchell (2014) Bailey's head and neck surgeryotolaryngology, Adenotonsillar Disease in Children, chapter 95, pp. 1430

9. Phưng Thị Vân Anh (2012), "Đánh giá kết quả tạo hình màng nhĩ đướng ống tai", Luận văn tốt nghiệp thạc sỹ, trường Đại học Y Hà Nội.

\section{NGHIÊN CỨU ĐĂC ĐIỂM ĐAU TRONG BÊNNH ZONA THEO CÁC THANG ĐIỂM ĐAU XUẤT XỨ THẦN KINH}

\section{TÓM TẮT}

Cơ sở: Bệnh zona là một trong những bệnh da thường gặp, do virus Herpes Zoster gây nên. Đau trong zona là triệu chứng chức năng chính đưa bệnh nhân đến cơ sở y tế, đăc biêt là chuyên khoa Thần Kinh. Đau là biểu hiện đặc thù ở cả ba giai đoạn của bênh với tính chất đau thân kinh nổi bât. Rất khó lượng giá cảm giác đau nhưng một số thang điểm đau có thể dùng đê đánh giá mức độ và tính chất đau xuất xứ thần kinh như thang điểm LANSS và DN4. Mục tiêu: Áp dụng một số thang điểm đau quốc tế đánh giá mức độ và tính chất đau xuất xứ thần kinh trong bệnh zona. Phương pháp: Chúng tôi tiến hành nghiên cứu theo phương pháp mô tả cắt ngang, tiến cứu trên 73 bệnh nhân được chẩn đoán bệnh zona. Sử dung thang điểm đau LANSSS và DN4 để đánh giá mức độ và tính chất đau. Kết quả: $70 \%$ đến $90 \%$ bệnh nhân được đánh giá đau theo thang điểm đau xuất xứ thần kinh (LANSS). 60,3\% bệnh nhân có tính chất đau xuất xứ thần kinh điển hình (điểm LANSS từ 21 trở lên). $20 \%$ đến $80 \%$ bệnh nhân có tính chất đau đánh giá theo thang điểm đảau xuất xứ thân kinh bộ 4 câu hỏi (DN4). 95,9\% bệnh nhân có tính chất đau xuất xứ thần kinh điển hình (điểm DN4 từ 4 trở lên). Tính chất đau xuất xứ thần kinh và mức độ đau sau zona có mối tương quan chăt chẽ với tuổi bệnh nhân. Kết luận: Đau zona có các tính chất điển hình của đau xuất xứ thần kinh. Tuổi càng cao, càng có nguy cơ đau sau zona và các triệu chứng đau đánh giá theo điểm LANSS và bộ 4 cẩu hỏi (DN4) càng đây đủ.

Tư khóa: LANSS, DN4, đau xuất xứ thân kinh, bệnh zona.

\section{SUMMARY \\ STUDY ON CHARACTERISTIC FEATURES OF}

*Bệnh viện Da liễu trung ương

**Bệnh viênn Bãi Cháy Quảng ninh

***Bênh viên Bach Mai.

Chịu trách nhiệm chính: Phạm Thị Thu Hương

Email: drthuhuong01@gmail.com

Ngày nhận bài: 2.8.2021

Ngày phản biên khoa hoc: 29.9.2021

Ngày duyệt bài: 5.10 .2021

\section{NEUROPATHIC PAIN IN ZONA}

Background: Shingles is one of the common skin conditions, caused by the Herpes Zoster virus. Pain in shingles is a major functional symptom that brings patients to medical specialties, especially neurology. Pain is characteristic of all three stages of zona with prominent neuropathic pain. However, pain is difficult to evaluate. There are a number of international pain scales that can be used to assess the level and nature of neuropathic pain, such as the LANSS and DN4 scores. Objective: To apply some international pain scales to assess the level and nature of neuropathic pain in shingles. Methods: We conducted a crosssectional descriptive study of 73 patients diagnosed with shingles. We used LANSS and DN4 pain scales to assess the level and nature of neuropathic pain. Results: $70 \%$ to $90 \%$ of the patients suffering from pain were evaluated on the basis of neurological pain score (LANSS) $60.3 \%$ of patients had typical neuropathic pain (LANSS score of 21 or higher). $20 \%$ to $80 \%$ of patients were evaluated according to the Neuropathic pain set of 4 questions (DN4). $95.9 \%$ of patients had typical neuropathic pain (DN4 score of 4 or higher). Neuropathic pain and postoperative pain were significantly correlated with the age of patients. Conclusion: Shingles pain had typical properties of neuropathic pain. The higher the risk, the greater the risk of post-shingles and pain symptoms assessed after LANSS and the set DN4 questions.

Key words: LANSS, DN4, neuropathic pain, shingles.

\section{I. ĐẶT VẤN ĐỀ}

Bệnh zona là một trong những bệnh da thường gặp, do virus Herpes Zoster. Đau có thể biểu hiện cả ba giai đoạn của bệnh. Đau sau zona là tình trạng đau kéo dài trên một tháng sau khi nhiễm Herpes zoster (khi vùng da tổn thương đã lành hoàn toàn). Đau được giải thích theo cơ chế: tăng hoạt tính màng và phóng điện lạc vị, tăng mẫn cảm ngoại vi và mất kiểm soát ức chế.

Đau là triệu chứng cơ năng chính đưa bệnh nhân đến cơ sở y tế, đặc biệt là chuyên khoa Thần kinh và Da liễu. Đau trong giai đoạn tiên 